\title{
DA METÁFORA EM SUA FACE RETÓRICA
}

\author{
Diogo de França Gurgel ${ }^{1}$ \\ Universidade Federal Fluminense (UFF) \\ (D) https://orcid.org/0000-0003-4970-663X
}

\section{RESUMO:}

No presente trabalho, procuro mostrar que um esclarecimento prévio acerca do papel da metáfora nas barganhas de significado é elemento imprescindível para a constituição de uma Filosofia da Retórica. Para tanto, recorro ao tratamento precursor conferido por I.A. Richards ao tema da metáfora na obra intitulada The Philosophy of Rhetoric e proponho complementações ao mesmo a partir de uma concepção de aprendizado da linguagem de orientação wittgensteiniana.

PALAVRAS-CHAVE: Metáfora; Retórica; Semântica.

\section{ON METAPHOR IN ITS RHETORICAL VISAGE}

\begin{abstract}
:
In this work, I aim to show that previous clarification of the role of metaphor in bargaining of meaning is a core element in the make up of philosophy of rhetoric. To acheive this, I refer to the trail-blazing examination performed by I.A.Richards on the theme of metaphor in the work titled The Philosophy of Rhetoric, and I build upon this examination by applying a Wittgensteinian view of language learning.
\end{abstract}

KEYWORDS:Mmetaphor; Rhetoric; Semantics.

\footnotetext{
${ }^{1}$ Professor adjunto do Departamento de Filosofia da Universidade Federal Fluminense (UFF), Brasil. E-mail: diogo.gurgel@gmail.com Da metáfora em sua face retórica - Diogo de França Gurgel 


\section{Introdução}

É notório como pesquisadores provenientes das mais diversas áreas vêm, desde meados do século XX, convergindo para o estudo da Retórica. Autores como Chaïm Perelman, Stephen Toulmin, Barbara Cassin e os integrantes do Grupo $\mu$ contribuíram imensamente para a revitalização do campo e a leitura de seus textos tem entusiasmado gerações de estudiosos. Contudo, creio que, ao discutirmos os caminhos sugeridos por esses precursores, temos dado, de um modo geral, pouca atenção a uma das obras mais contundentes no que diz respeito aos serviços prestados em favor dessa revitalização ${ }^{2}$. Refiro-me a The Philosophy of Rhetoric, de I.A.Richards. Suponho que uma das razões para essa negligência resida no fato de que o mais célebre canal de divulgação da obra foi estabelecido por Max Black, em um artigo que, por um lado, é extraordinariamente contundente e seminal em sua abordagem do tema da metáfora, mas, por outro lado, termina por obscurecer o projeto de Richards como um todo. Black, em seu artigo intitulado "Metaphor", a um só tempo alinha-se com a teoria interacionista da metáfora fundada por Richards e isola essa teoria de todos os demais desenvolvimentos argumentativos presentes em The Philosophy of Rhetoric. Ao fazê-lo, ele negligencia as contribuições de Richards para a inserção da metaforologia no seio de uma Retórica reestabelecida como campo promissor para investigações acerca da natureza do significado.

Diante desse quadro, interessa-me fazer notar como o trabalho de Richards é orientado na contramão de toda uma tradição de "amputação" da Retórica - para usar os termos de Paul Ricoeur em La Métaphore Vive (RICOEUR 1975, p.13). Refiro-me a uma tradição teórica que foi destituindo gradativamente a metáfora da relevância filosófica de que gozava na obra de Aristóteles e que, na mesma medida, foi reduzindo a Retórica a um mero estudo dos tropos, a uma mera teoria da elocução. Trata-se de um processo que tem início já na leitura que retores latinos como Cícero e Quintiliano fazem da retórica grega e que encontra sua culminância no pretenso embargo promovido por renomados filósofos (dentre os quais John Locke ${ }^{3}$ ) à metáfora em seus escritos teóricos.

Richards procura resgatar a dignidade filosófica da Retórica ao tomá-la como um estudo da compreensão e da incompreensão verbal (RICHARDS 1965, p.23). A Retórica, segundo o autor, deve ser vista como a arte do discurso, i.e., como uma disciplina filosófica que almeja o domínio das regras fundamentais de uso da linguagem e não apenas como um conjunto de artimanhas que parecem funcionar eventualmente. De modo sucinto, pode-se afirmar que a obra de Richards é dedicada a reestabelecer os direitos do discurso no cenário do estudo da linguagem - isso tendo em

\footnotetext{
${ }^{2}$ E tal contundência se deve tanto ao seu caráter precursor (a obra foi publicada em 1936) quanto à força de seus argumentos.

${ }^{3}$ p.ex.: LOCKE, Essay Concerning Human Understanding, III, 10, p.34.
} 
vista que a filosofia da linguagem prevalescente à época tinha por método o exame de extratos de linguagem ao nível da palavra e ao nível da sentença (trabalhando, em geral, com asserções), o que deixava desguarnecido o nível da articulação entre sentenças, ou seja, o nível do discurso como um todo.

Assumo que é somente nesse contexto de reabilitação da Retórica que se pode compreender devidamente a definição de metáfora elaborada por Richards e aclamada por Black. A discussão do texto de Richards, como veremos, conduz naturalmente a uma aporia acerca do estatuto semântico da metáfora, abrindo espaço para um segundo objetivo que persigo neste trabalho, a saber, o de contribuir para o estudo dos liames entre metaforologia e Retórica a partir da apresentação de certas operações peculiares que certas metáforas desempenham nos conflitos e barganhas de significado ocorrentes em nossas práticas linguísticas. É preciso perguntar: o que faz de uma recategorização, de uma inovação semântica via metáfora, um recurso retórico significativo? Nesse momento do trabalho, lançarei mão - ainda que com ressalvas - da concepção de aprendizado da linguagem desenvolvida por Wittgenstein nas Investigações Filosóficas e, nessas bases, procurei mostrar o quão promissora pode ser a ideia richardiana de que metáforas são formas discursivas que possibilitam transações entre contextos (RICHARDS 1965, p.94).

\section{A retórica segundo Richards}

Examinemos alguns pontos-chave de The Philosophy of Rhetoric. Penso que o primeiro ponto a se enfatizar é que o título já diz bem a que vem a obra. Trata-se de um projeto de resgate da dignidade de um certo campo das pesquisas filosóficas. A Retórica, essa disciplina que já foi tomada por Aristóteles como contraparte da dialética (ARISTÓTELES 2000b, 354a 1), como lugar de um tipo específico de argumento dedutivo, como lugar de análise de formas de discurso caríssimas à vida pública, como o são os discursos deliberativo e forense, veio sendo gradativamente rebaixada, chegando finalmente à classe das disciplinas periféricas de estudo de ornatos e floreios de linguagem. A tropologia moderna, com seu estudo do estilo, já não fazia jus, nos séculos tidos como modernos, nem mesmo ao estudo clássico da léxis, o qual, por sua vez, fora somente uma parte da Retórica em toda a sua envergadura. Richards reconhece na nascente filosofia da linguagem e na crítica literária de sua época a lacuna a ser preenchida por uma perspectiva de análise da linguagem que, originalmente, cabia à Retórica.

Assumindo para si a incumbência de denunciar e desfazer, dentro do possível, esse desserviço histórico, Richards propõe, já na primeira página do livro, que a Retórica seja tomada como "o estudo das incompreensões e de seus remédios" (RICHARDS 1965, p.3). A distinção entre a boa é a má comunicação, sugere ele, não pode se dar senão no seio de um estudo de 
Retórica, de um estudo filosófico que procura pelas leis fundamentais que regem o uso da linguagem (RICHARDS 1965, p.3). O autor assume (fazendo coro ao Arcebispo Whateley) que a Retórica não é uma arte do discurso, mas $a$ arte do discurso e complementa, mais à frente, dizendo que

\begin{abstract}
a persuasão é apenas uma dentre as finalidades do discurso. Ela canibaliza as outras - especialmente aquela da exposição, a qual procura estabelecer uma visão e não persuadir pessoas a concordar ou a fazer qualquer outra coisa que não examiná-la. (RICHARDS 1965, p.24).
\end{abstract}

Perceba-se que, com esse posicionamento, Richards dá a entender que nem mesmo Aristóteles - o qual assumia que a persuasão é a espinha dorsal e a finalidade última da Retórica - considerou essa disciplina em toda a sua potência.

Fica clara também a intersecção traçada por Richards entre Retórica e Semântica nas diversas passagens em que assume que recai sob o escopo da Retórica, tal e qual ele a compreende, a lida com a questão "Como palavras significam?". Em uma dessas passagens ele diz:

\begin{abstract}
O resultado é que uma Retórica ressuscitada, ou estudo das compreensões e incompreensões verbais, deve ela mesma protagonizar sua própria investigação sobre os modos do significado - não apenas tal e qual a velha Retórica, em uma escala macroscópica, discutindo os efeitos de diferentes disposições de largas partes do discurso - mas também em uma escala microscópica, valendo-se de teoremas sobre a estrutura das unidades de significado conjecturais fundamentais e sobre as condições por meio das quais surgem elas e suas interconexões. (RICHARDS 1965, pp. 23-24)
\end{abstract}

Esse tratamento retórico do problema semântico do significado leva Richards à seguinte tese: "o que uma palavra significa são as partes faltosas dos contextos a partir dos quais ela traça sua eficácia delegada" (RICHARDS 1965, p.35). Vem embutida nessa tese uma inusitada inversão de papéis entre texto e contexto: o contexto seria algo que pode - em uma situação ideal - ser compreendido por si mesmo (prescindindo do texto), porém, alguns de seus componentes (tipicamente palavras) nos habilitariam a fazer o que Richards chama de "abreviações" (abridgements) de contexto, i.e., o texto funcionaria primariamente completando o contexto, permitindonos afigurar seus eventos omissos (como causas ou efeitos, por exemplo).

Entretanto, um problema de que padece essa concepção de significado é a vagueza do termo "contexto". Assumo que a definição técnica de contexto fornecida por Richards como "grupo de eventos recorrente" (RICHARDS 1965, p.34) está longe de ser satisfatória para os fins de uma semântica das metáforas. Esse ponto será explorado na terceira seção do presente trabalho. 
Penso que os apontamos que fiz acima, ainda que breves, são suficientes para que tenhamos uma ideia geral do projeto richardiano de reabilitação e enriquecimento da Retórica. Passemos agora a uma consideração da teoria da metáfora por ele desenvolvida e de sua articulação com a totalidade do projeto.

\section{A metáfora como recurso retórico em Richards}

Em primeiro lugar, é preciso notar que o estudo da metáfora decorre naturalmente, no desenvolvimento da obra - a qual é, na verdade, uma reunião de palestras, de lectures -, de uma crítica da superstição do significado próprio ("uma relíquia que remonta à crença em nomes mágicos" - RICHARDS 1965, p.71) e de uma preocupação com o desenvolvimento de um método de estudo que nos permita acompanhar as mudanças de significado próprias das línguas vivas. Ao fim da Lecture IV, Richards deixa o cenário preparado para a tematização da metáfora e de suas funções didáticas - já antecipadas por Aristóteles (ARISTÓTELES 2000b, 1412a 30-35) - ao propor uma breve discussão sobre "as razões para a escolha de palavras" e ao apontar para um vasto campo de estudo em que se pudesse trabalhar com vistas a transformar essa discussão em uma disciplina central dos saberes educacionais (RICHARDS 1965, p.86).

Em segundo lugar, devo deixar claro que Richards não busca uma taxionomia dos tipos de metáfora - tarefa considerada infrutífera para quem, como ele, não perde de vista que a linguagem está em constante mutação -, mas sim uma clarificação de nossa habilidade de compreensão da metáfora.

A definição mais célebre de metáfora fornecida pelo teórico inglês (corroborada por Max Black e fundadora de toda uma corrente de teóricos da metáfora) é a seguinte: "quando nós usamos uma metáfora, nós temos dois pensamentos sobre coisas diferentes concomitantemente ativos e operando em uma palavra, ou frase, cujo sentido é a resultante de sua interação" (RICHARDS 1965, p.93). Mais adiante no texto, ele apresenta uma elucidação complementar, dizendo que a metáfora é uma "transação entre contextos" (RICHARDS 1965, p.94). A proposta do autor para a efetuação de uma análise devida dessa transação, conforme ela ocorre na sentença, é de que denominemos "conteúdo" (tenor) a ideia subjacente e "veículo" (vehicle) a ideia a partir da qual a primeira é apreendida. Deve-se notar, porém, que a metáfora como Richards a concebe não se deixa reduzir nem ao conteúdo nem ao veículo, ela não é senão a interação entre os dois. $\mathrm{E}$, assim, na grande maioria dos casos, "metáfora" é nome que devemos usar para nos referirmos às sentenças em que ocorre essa transação entre contextos, essa interação entre pensamentos que se apresenta na linguagem por meio de proferimentos em que a predicação é impertinente em face aos hábitos gramaticais de uma determinada comunidade. 
Desse modo, de acordo com Richards, ao apresentar uma metáfora, o emissor joga com os hábitos linguísticos de seu(s) interlocutor(es), concedendo um significado literal (canônico, habitual) a pelo menos um dos termos que compõem a sentença metafórica e forçando o emprego do(s) outro(s) termo(s) em um contexto que não lhe(s) é próprio, de modo a produzir um sentido sentencial inusitado, fruto de uma predicação transgressora. O estudo da metáfora empreendido por Richards, como se vê, é parte de sua agenda de investigação das vias diversas pelas quais logramos obter o compartilhamento de significado, evitando certas falhas de comunicação.

É preciso ainda ressaltar uma série de outros méritos de Richards no que tange às suas contribuições para as teorias contemporâneas da metáfora: ele foi, por exemplo, um dos precursores no questionamento da semelhança pré-existente como dispositivo hegemônico de composição e compreensão da metáfora (RICHARDS 1965, pp.107-108). Suas considerações a esse respeito levam Black a afirmar que "seria mais esclarecedor, em alguns desses casos, dizer que a metáfora cria a semelhança, do que dizer que ela formula alguma similaridade anteriormente existente" (BLACK 1955, p.284-285).

Ademais, o trabalho de Richards é digno de reconhecimento não somente por apresentar uma abordagem da metáfora que a põe na ordem do dia da filosofia da linguagem, mas também por deixar evidente que um enriquecimento da Retórica envolve necessariamente uma revisão minuciosa dos tratamentos dados ao tema da metáfora.

Contudo, é também imperativo fazer a denúncia de uma grave ausência remanescente nesse projeto. A teoria da metáfora desenvolvida por Richards deixa sem resposta uma questão crucial acerca do estatuto semântico das metáforas, a saber: como certas inovações semânticas funcionam e outras não? Como distinguir, por exemplo, uma metáfora de um puro e simples nonsense no que tange à compreensão da linguagem? E agrava essa lacuna o fato de Richards contestar textualmente Aristóteles por ter esse último afirmado na Poética que o "olho para semelhanças" é um dom natural (RICHARDS 1965, p.89). O inglês dispara a crítica e, no entanto, não faz mais no sentido de suprir a carência teórica constatada do que afirmar que a metáfora nos permite "tornar nossas recognições implícitas em distinções explícitas" (RICHARDS 1965, p.95).

Mas ganhemos um pouco mais de clareza com relação ao problema que temos em mãos. A perplexidade em que caímos ao tentar determinar as razões pelas quais certas inovações linguísticas funcionam e outras não pode ser demarcada com as seguintes questões: como pode uma transgressão gramatical ser significativa? E neste sentido, a teoria de Richards, com suas metáforas da metáforas - tais como "veículo" e "interação" -, não pode nos prestar muitos serviços. 
Diante desse impasse, sugiro uma revisão das definições de metáfora elaboradas por Richards na obra em exame. Uma revisão que nos conduz, assim penso, a uma crítica do polissêmico conceito de contexto a partir das concepções apresentadas por Wittgenstein nas Investigações Filosóficas. Suspeito que procedendo dessa forma, conseguiremos importantes esclarecimentos acerca do modo como um estudo retórico pode ser feito de modo a solucionar o problema das transgessões significativas - ou, como prefere Nelson Goodman, dos "erros-categoria calculados" (GOODMAN 1976, p.73) - promovidos pelas metáforas.

\section{Contribuições de Wittgenstein para uma compreensão da metáfora como recurso retórico}

Uma advertência deve ser feita para que se possa avaliar devidamente a pertinência da tese que exponho abaixo: a questão dos limites da recategorização via metáfora é uma questão filosófica de grande envergadura e não tenho pretensão de apresentar nenhuma solução exaustiva e cabal para o mesma no presente trabalho. Digo isso até mesmo porque não me parece plausível o projeto de se encerrar em uma só fórmula todos os diversos tipos de construção linguística que vêm recebendo e podem receber o nome "metáfora". Ficarei bastante satisfeito se o tratamento que venho desenvolvendo até o momento para tal questão se mostrar promissor para a compreensão de certas metáforas que envolvem no mais alto grau o que Paul Ricoeur chama de "veemência ontológica" (RICOEUR 1975, p.321), i.e., se esse tratamento nos permitir ganhar alguma clareza sobre como funcionam metáforas por meio das quais procuramos descrever fatos e definir significados do modo mais apropriado ${ }^{4}$. Esse é o caso de muitas sentenças metafóricas empregadas em práticas linguísticas de cunho político, tais como "Estamos do mesmo lado" ou, para mencionar um célebre exemplo fornecido por Lakoff e Johnson em Metaphors We Live By, "Discussão é guerra" (LAKOFF; JOHNSON 2003, p.4).

Feita essa advertência, consideremos os ganhos que obtemos ao abandonar o conceito de contexto e ao trabalhar com o conceito de jogo de linguagem em nosso estudo de Retórica. Tomemos como fio condutor de nosso raciocínio a concepção wittgensteiniana de que compreender o significado de um signo é compreender seus usos nos jogos de linguagem

\footnotetext{
${ }^{4}$ Trataremos, pois, de um certo tipo de metáfora em que a exigência de recategorização se faz muito forte, i.e., um certo tipo em que a consideração efetiva da sentença metafórica como asserção, como descrição de fatos, é um imperativo para a compreensão. Não são metáforas que admitem paráfrases literais na forma de símile (na forma "S é como P"). Elas têm traços de catacrese, preenchem lacunas semânticas e, ao mesmo tempo, têm traços de metáforas de invenção, transgridem as regras de uso habitual dos signos. Refiro-me a sentenças metafóricas que, postas na fórmula aristotélica simples, "S é P" não querem senão dizer "S é P", efetivamente, ou seja, que se comprometem com a asserção feita nos termos em que ela é feita.
} 
em que ocorre - levando em conta que trabalhar com a mesma implica em se assumir que o estudo de semântica envolve o estudo do aprendizado do uso dos signos (PI, §43, §138). Dado que uso não é senão comportamento linguístico, investigar o que possa ser a compreensão do sentido de uma sentença $p$ requer investigar as regras de uso de signos que vigora nas práticas sociais regradas em que tal sentença ocorre. A essas práticas Wittgenstein dá o nome de "jogos de linguagem" (WITTGENSTEIN 2006, $\S 7 ; \S 23)^{5}$.

Munidos desse conceito, podemos evitar recorrer ao sempre obscuro conceito de contexto em nossa investigação sobre o poder de recategorização das metáforas. Por seu emprego excessivo em teorias as mais diversas, sendo mesmo algumas delas antagônicas entre si, o termo "contexto" tornou-se demasiadamente vago. Tornou-se difícil encontrar modos de preservar o conceito a ele relacionado de empregos comprometidos com a ideia de que os aspectos semânticos de uma sentença podem ser analisados isoladamente de aspectos pragmáticos e fonéticos - o que conduz, em geral, a algum tipo de semântica mentalista. Além disso, a determinação dos domínios de um jogo de linguagem é consideravelmente mais precisa do que a determinação dos domínios de um contexto: podemos nos focar nos verbos de ação, como faz Wittgenstein nas Investigações Filosóficas:

(...) O termo "jogo de linguagem" deve aqui salientar que o falar da linguagem é uma parte da uma atividade ou de uma forma de vida.

Imagine a multiplicidade dos jogos de linguagem por meio destes exemplos e outros:

Comandar, e agir segundo comandos -

Descrever um objeto conforme a aparência ou conforme medidas -

Produzir um objeto segundo uma descrição (desenho) -

Relatar um acontecimento -

Expor uma hipótese e prová-la -

Apresentar os resultados de um experimento por meio de tabelas e diagramas-

Inventar uma história; ler -

Representar teatro -

Cantar uma cantiga de roda -

Resolver enigmas -

Fazer uma anedota; contar -

Resolver um exemplo de cálculo aplicado -

Traduzir de uma língua para outra -

\footnotetext{
${ }^{5}$ Refiro-me aqui a uma acepção do conceito de jogo de linguagem que abarca práticas linguísticas complexas, como contar uma piada ou celebrar uma missa e não estou trabalhando com outras acepções também presentes na obra. Não tenho em mente, por exemplo, jogos de linguagem forjados, os quais funcionam como objetos de comparação (WITTGENSTEIN, 2006, §130).
} 
Pedir, agradecer, maldizer, saudar, orar. (...) (WITTGENSTEIN, 2006, §23)

Ao nos valermos dos métodos de investigação gramatical desenvolvidos por Wittgenstein, encontramos um modo de abordar o tema da metáfora por uma perspectiva do discurso (do jogo de linguagem) afastando-nos das abordagens limitadas ao nível da palavra desviada ou ao nível da predicação impertinente - e esse é um fator decisivo. A metáfora aparece como lance no jogo de linguagem (WITTGENSTEIN, 2006, §49) antecedida e sucedida por outros lances. Essa pode ser, penso, uma contribuição valiosa do pensamento de Wittgenstein para um projeto de reabilitação e enriquecimento da Retórica.

Precisamos, contudo, que nossa compreensão do conceito de jogo de linguagem ganhe em sofisticação, de modo a podermos ver como ele nos auxilia com nosso tratamento da metáfora. Proponho considerarmos os jogos de linguagem não pela perspectiva do simples aprendizado da regra canônica, mas, sobretudo, pelo ponto de vista da equivocidade e da barganha de regras que encontramos em jogos mais complexos do que a grande maioria dos jogos descritos por Wittgenstein em seus escritos de maturidade ${ }^{6}$. Ao invés de nos focarmos na convergência de certos comportamentos linguísticos, deixemo-nos instigar por filósofos que se aventuraram a pensar os conflitos normativos presentes em nossas práticas linguísticas, tais como Grice, Davidson e Bakhtin ${ }^{7}$.

Um resgate do interacionismo de Richards devidamente inserido em seu projeto de uma filosofia da retórica exige de nós que nos perguntemos aonde pode nos conduzir o insight de que um metáfora é uma "transação entre contextos" (RICHARDS 1965, p.94) e que, nela, encontramos "dois pensamentos concomitantemente ativos". E, do modo como compreendo, uma concepção agonística de jogo de linguagem pode lançar alguma luz em nosso caminho.

Deixemos que uma suspeita assuma as rédeas de nossa investigação, a saber, a suspeita de que a impertinência de predicação envolvida nas asserções efetuadas por certas metáforas seja uma marca de conflito normativo entre jogos de linguagem ou entre diferentes níveis normativos de um mesmo jogo. Para termos um bom exemplo da concomitância entre jogos de linguagem, basta considerarmos dois ou mais dos jogos

\footnotetext{
${ }^{6}$ Não nos ocuparemos aqui, portanto, com jogos de linguagem simples como o da compra de maçãs (WITTGENSTEIN 2006, §1), os quais foram construídos por Wittgenstein com o intuito de investigar certas regras envolvidas em uma prática linguística definida e não tendo em vista possíveis regras latentes, cuja entrada em vigor permitiria um deslocamento entre práticas linguísticas.

${ }^{7}$ Refiro-me especificamente aos textos "Logic and Conversation", de Paul Grice, "A Nice Derangement of Epitaphs", de Donald Davidson e Marxismo e Filosofia da Linguagem, de Bakhtin. O artigo "Idiolect and Context", de Carlo Penco, também faz grande contribuição a esse tema.
} 
enumerados por Wittgenstein na passagem reproduzida acima ocorrendo a um só tempo: um padre conta uma piada (jogo 1) que exige uma tradução entre duas línguas (jogo 2) em meio a uma missa (jogo 3) $)^{8}$. Para termos um bom exemplo de multidimensionalidade do jogo de linguagem, i.e., do fato de um jogo apresentar diversos níveis normativos, tomemos de empréstimo uma passagem do belo texto de Umberto Eco, Seis Passeios pelos Bosques da Ficção. Refiro-me ao momento em que Eco menciona a "piscadela" que o autor de Pinóquio, Carlo Collodi, dá para seu público adulto - e exclusivamente para esse público - em meio a uma narrativa para crianças. Ao começar a narrativa dizendo: "Era uma vez... um rei!, dirão de imediato meus pequenos leitores. Não, crianças, estão enganadas. Era uma vez um pedaço de madeira.", Collodi atua em dois níveis diferentes do jogo de linguagem da narração de histórias. Ele narra o conto de fada às crianças e promove essa quebra de expectativa que "poderia indicar [aos adultos] que deveriam ler a história sob uma luz diferente e, ao mesmo tempo, fingir-se de crianças para compreender os significados alegóricos da narrativa" (ECO 2004, p.16).

A concepção da prática comunicativa que se pode delinear a partir do conceito de jogo de linguagem, mediante uma revisão do pressuposto infundado de que só operamos com um sistema normativo por vez, fornecenos um instrumental que penso ser satisfatório para descrever o surgimento de muitos novos significados via metáfora, respeitando a distinção entre os mesmos e o mero nonsense. Se considerarmos que metáforas podem ser recursos discursivos que estabelecem transações entre jogos de linguagem (e aqui a preposição deve ser devidamente enfatizada) e que a concomitância de pensamentos não é senão concomitância de dois sistemas normativos distintos em uma mesma sentença, temos o seguinte: a metáfora se mostra recurso de transferência de regras de uso dos signos de um sistema descritivo para outro. $\mathrm{O}$ lance de linguagem metafórico começa em um jogo de linguagem e termina em outro (ou em outro nível do mesmo jogo). Ocorreria, assim, nesse tipo de metáfora, o que Nelson Goodman certa feita denominou "erro-categoria calculado" (GOODMAN 1976, p.73). E o cálculo consistiria nisso: ao proferir uma sentença metafórica na forma "S é P", o emissor apresentaria ao receptor o termo S (o qual ocupa a posição de sujeito) numa acepção que é familiar ao receptor, contudo, aplicaria a ele um predicado inesperado (cujo elemento central é o termo P), transgressor, ainda que não incompreensível.

Assim, decifrar o enigma da metáfora não é senão tornar-se capaz de ver o jogo de linguagem em que ela é literal como o jogo atual (se não falo necessariamente em se deixar convencer pela metáfora cetagórica, falo, ao

\footnotetext{
${ }^{8}$ Podemos relembrar também aquela passagem das Investigações em que a polissemia da palavra "jogo" abre espaço para que um adulto a quem foi dada a incumbência de ensinar um jogo às crianças ignora o que quis dizer quem lhe fez o pedido e ensina as crianças a jogar dados a dinheiro (WITTGENSTEIN, 2006, §70).
} 
menos, em compreender o que está em jogo quando o emissor se vale desse tipo de asserção: ele procura efetuar uma transferência normativa de um jogo A para um jogo B mediante uma inserção (ou exclusão) de um sujeito $S$ em uma classe P. Dado que a defecção da inserção (ou exclusão) em classe proposta em um jogo A não é admissível, o receptor deve procurar por um uso não canônico de $\mathrm{P}$ que possa comportar a relação com $\mathrm{S}$. De acordo com Sam Glucksberg e Boas Keysar, esse uso não canônico não guarda com o uso canônico uma relação de homonímia. Uma metáfora categórica (que diz "S é P" e quer dizer efetivamente "S é P"), em boa parte dos casos, envolve um uso extensionalmente ampliado do termo $\mathrm{P}$, de modo que o conceito possa admitir todos os membros típicos e mais outros membros, dentre eles, $S$ (no caso de uma inclusão em classe e não de uma exclusão) (GLUCKSBERG; KEYSAR, 1990, p.7).

Por exemplo, em um jogo de linguagem em que um emissor caracteriza sua atividade profissional dizendo: "Meu trabalho é uma prisão", o termo "prisão" abarca não somente celas e afins, mas situações em que um indivíduo é mantido, contra a sua vontade, em grande desconforto. Ou seja, propriedades canônicas como a do confinamento decorrente de infração da legislação devem ser ocultadas para que o receptor possa compreender devidamente o conteúdo da asserção e seu valor de verdade.

$\mathrm{O}$ que eu estou trazendo como contribuição a esse modelo de metáfora como inclusão em classe proposto por Glucksberg e Keysar é a ideia de que o que distingue uma metáfora categórica como "Meu trabalho é uma prisão" de uma sentença literal como "Bangú 1 é uma prisão" é o fato de que a inclusão em classes via metáfora força uma transição entre jogos de linguagem concomitantes (ou níveis normativos de um mesmo jogo), estabelecendo uma transferência de regras de uso de determinados signos.

Esse acréscimo visa dar um tratamento mais satisfatório ao problema da inovação semântica via metáfora, i.e., ao problema dos critérios de distinção entre metáforas novas e o nonsense - problem esse que, como vimos, foi negligenciado por Richards. Com a transação entre jogos de linguagem, abre-se caminho para a compreensão de como uma metáfora categórica pode operar nomeando uma categoria já funcional (atuante) em uma comunidade linguística, porém, carente de um nome próprio. Trabalho com a evidência, notada originalmente por Barsalou, de que nem todas as categorias funcionais em nossa linguagem possuem um nome que lhes é próprio (BARSALOU 1983, 211). Esse é o caso, por exemplo, em nossa comunidade linguística, da classe dos objetos que não devem ficar à vista dos convidados na ocasião de uma festa em casa ou da classe dos termos que não se deve usar em uma entrevista de emprego. Trazendo essa constatação para a discussão sobre a metáfora, defendo que uma sentença como "Meu trabalho é uma prisão", ao nos levar a alterar extensão do conceito de prisão, remete-nos a uma categoria funcional anônima que admite receber o nome "prisão". 
Assegura-se, com base nesse instrumental, que a inovação semântica via metáfora categórica tenha seu lastro não em um mero arbítrio idiossincrático (o que tornaria o compartilhamento do significado um mistério insolúvel), mas em uma demanda da comunidade. A nomeação de categorias funcionais anônimas, tendo e vista que estas já são atuantes na orientação de nossas ações e podem ser expressas por descrições definidas, guarda uma distância segura de toda a sorte de abusos gramaticais.

Se esse encaminhamento dado ao tema procede, abre-se espaço para a elucidação de alguns pontos intrincados que vêm, tradicionalmente, assolando pesquisadores. Dentre eles, aquele que formulei acima da seguinte forma: a partir de quais critérios pode um falante diferenciar uma predicação impertinente significativa de outra não significativa? Diante dessa questão, agora podemos dizer que nenhum deus ex machina é necessário para respondê-la. A pura e simples consideração de nosso aprendizado da linguagem pela perspectiva de sua vagueza endógena - i.e., das lacunas normativas produzidas por esse processo -, dos jogos de linguagem por uma perspectiva agonística e, é claro, das habilidades envolvidas na identificação desses efeitos, já nos proporciona o material de que precisamos para a elucidação. A alteração da extensão do termo $\mathrm{P}$ ocorrente na metáfora categórica permite aos falantes nomear categorias anônimas, de modo ad hoc, mediante um processo de ênfase e ocultação de propriedades já canonizadas pelo uso corrente que é perfeitamente compreensível ainda que inusitado. Uma metáfora desse tipo se difere de um mero nonsense, pois seus processos de composição e interpretação obedecem regras claras de seleção de propriedades. O cálculo de que fala Goodman, seria portanto, a ênfase e a ocultação de certas propriedades que infringimos ao(s) referente(s) canônico(s) do termo $\mathrm{P}$ de modo a nomear uma nova categoria sem, contudo, abrir mão de outras propriedades típicas - do contrário, arruinar-se-iam as possibilidades hermenêuticas.

\section{Conclusão}

Após duas seções em que fiz uma breve apresentação do projeto richardiano de reabilitação e enriquecimento da Retórica, procurei defender a tese de que metáforas comprometidas com a recategorização (dotadas de veemência ontológica) podem ser vistas como recursos de deslocamento normativo entre jogos de linguagem ou entre níveis de um mesmo jogo de linguagem. Espero ter deixado claro que o primeiro e mais fundamental ponto de contato entre as obras de Richards e Wittgenstein - e que me permite ver pertinência nessa complementação do trabalho de um com o trabalho do outro - está na postura comum de que o estudo da estrutura semântica de uma sentença (metafórica ou não) só pode se dar de modo satisfatório quando se contempla a articulação entre essa sentença e as demais sentenças que compõem o discurso em que a primeira está inserida. 
Essa perspectiva de análise que contempla o discurso como um todo, levando em conta as regras da interlocução, é classicamente atribuída à Retórica e à Dialética, como disciplinas irmãs que são. Gostaria de explorar um pouco mais essa ideia agora que caminhamos para o desfecho do trabalho.

Pensar a metáfora como uma estratégia discursiva situa-nos no seio de um estudo que Richards certa feita chamou de "estudo da incompreensão e de seus remédios" (RICHARDS 1965, p.3) - e nos leva admitir que, dentre estes remédios, devem estar presentes as estratégias discursivas de transição entre jogos de linguagem e entre seus diversos níveis. É esse o ponto de vista que a Retórica nos faz assumir com relação ao estudo da linguagem: o ponto de vista que toma cada proferimento como um ato na totalidade do discurso (como um lance no jogo de linguagem). Esse é, do modo como compreendo, o ponto de vista peculiar que funda Aristóteles, ao abrir a Retórica afirmando que esse campo do saber é a contraparte da dialética e deixando entrever, como nota Ricoeur, "um vínculo entre o conceito retórico de persuasão e o conceito lógico de verossímil" (RICOEUR 1975, p.17). Ao fazê-lo, o filósofo deixa entrever que tanto a Dialética quanto a Retórica tratam da interlocução e colocam em primeiro plano os recursos de condução do pensamento que se mostram nas escolhas vocabulares de um orador - nas seleções de aspectos relevantes de que ele se vale para apresentar os fatos, "colocar a coisa diante dos olhos" (ARISTÓTELES 2000b, III, 1405b 14-15). Ambas subsumem a exposição de pensamentos à comunicação, onde o que está em jogo são os papéis dos proferimentos no discurso como um todo.

Certas metáforas reivindicam o posto de descrições de fatos, de asserções, e são usadas como tais. A que disciplina compete estudar essa reivindicação? Um estudo dos diversos tipos de descrição compete à Retórica, na medida em que podemos ver, em cada um deles, seleções de aspectos relevantes para um determinado contexto (um determinado procedimeto, um auditório particular, para falar como Perelman). O estudo dos modos de edição é um estudo retórico, é o estudo das técnicas de condução envolvidas no discurso. A Retórica, pensada desta maneira, permite-nos abordar a linguagem a partir dos jogos de linguagem em sua forma enriquecida, i.e., contemplando a concomitância e a multidimensionalidade dos mesmos. E, ao tratar de descrições, trata não apenas de descrições feitas em jogos de linguagem, mas também das descrições de jogos de linguagem e da transição entre jogos de linguagem.

Vimos que Richards defende um alargamento da metáfora tanto rumo à dimensão da semântica e da sintaxe (filosofia da linguagem) quanto rumo à dimensão do discurso político e dos demais gêneros discursivos (incluindo-se o especulativo ou científico). As complementações que proponho para esse projeto, a partir de Wittgenstein, não são senão uma tentativa de torná-lo ainda mais contundente. 


\section{Referências bibliográficas}

ARISTÓTELES. Poetics. Tradução de Stephen Halliwell. 2.ed. London: Harvard University Press, 2000a. (In: Loeb Classical Library, v.199) - Art of Rhetoric. Tradução de J. H. Freese. London: Harvard University Press, 2000b. (Loeb Classical Library, v.193)

BAKHTIN, M. Marxismo e filosofia da linguagem. Tradução de Michel Lahud e Yara Frateschi Vieira. 14. ed. São Paulo: Hucitec, 2010.

BARSALOU, L.W. Ad hoc categories. Memory and Cognition. v.11, n.3, p.211-227, 1983.

BLACK, M. Metaphor. In: JOHNSON, M. (Org.) Philosophical Perspectives on Metaphor. Minneapolis: University of Minnesota Press, p. 63-82, 2011.

DAVIDSON, D. A Nice Derangement of Epitaphs. The Essential Davidson. Oxford: Oxford University Press, p.251-265, 2006.

ECO, U. Seis passeios pelos bosques da ficção. Tradução de Hildegard Feist. São Paulo: Companhia das Letras, 2004.

GLUCKSBERG, S; KEYSAR, B. Understanding metaphorical comparisons: beyond similarity. Psychological Review, v.97, n.1, p.3-18, 1990.

GOODMAN, N. Languages of Art: An approach to a Theory of Symbols. Indianapolis: Hackett, 1976.

GRICE, P. Logic and Conversation. In: GRICE, P. Studies in the way of words. London: Harvard, 1991.

LAKOFF, G.; JOHNSON, M. Metaphors We Live By. Chicago: The University of Chicago Press, 2003.

LOCKE. An Essay Concernig Human Understanding. Chicago: Encyclopædia Britanica (William Benton Publisher), 1952.

PENCO, C. Idiolect and Context. In: AUXIER, R.E.; HAHN (Eds.). The Philosophy of Michael Dummett. Chicago: Open Court, 2007, pp.267-590 (The Library of Living Philosophers, v.31)

RICHARDS, I.A. The Philosophy of Rhetoric. Oxford: Oxford University Press, 1936.

RICOEUR, P. La Métaphore Vive. Paris: Éditions du Seuil, 1975.

WITTGENSTEIN, L. Tractatus Logico-Philosophicus; Tagebücher 19141916; Philosophische Untersuchungen. Frankfurt am Main: Suhrkamp, 2006. (Suhrkamp taschenbuch wissenschaft, v.501)

. The Blue and Brown Books. Oxford: Basil Blackwell, 1969.

Autor(a) para correspondência: Diogo de França Gurgel, Universidade Federal Fluminense, Centro de Estudos Sociais Aplicados, Rua Professor Marcos Valdemar Freitas Reis, s/n, Faculdade de Educação, Campus do Gragoatá, São Domingos, CEP 84269090, Niterói - RJ, Brasil. diogo.gurgel@gmail.com 